\title{
Matthias Tarasiewicz
}

\section{QUERY PUBLIC(S) IN THE}

NEXT SOCIETY: »ARTISTIC TECHNOLOGY RESEARCH« AS [DISPOSITIF] AND SYNERGETIC DISCIPLINE FOR THE AGENCY OF RESEARCH AND DEVELOPMENT IN NEXT (MEDIA) CULTURES

APRJA Volume 2, Issue 1, 2013

ISSN 2245-7755

CC license: 'Attribution-NonCommercial-ShareAlike'. 
Critical Media Arts do not only reflect on new technologies and how they transform society, they also offer a crucial laboratory for the development of new techniques and forms of presenting, structuring and conveying knowledge.

New Media Arts in the 21st century work with distributed publics and identities, as the new media artists present their artistic processes "coded"[1] in the fragmentations of global networks. Terms such as "postinternet art" (Marisa Olson), "really new media art" and "internet aware art" (Guthrie Lonergan) describe a contemporary artistic and creative practice with a world view and concept of reality that emerged from virtual space permeating real life, creating a fusion of both and leading to something new: the hyperlocal world as we know it today (cf. Pang). Inke Arns writes about a "post-medial condition"[2] that can be succinctly described with the idea "code is law" (Lessig, Code is Law). "Medialities, dispositives and performances accompanying and elaborating medial processes" (translated from Mersch) are essential to describe, reflect and visualize a contemporary practice in New Media Arts should it be needed to keep this categorization or name alive.

Actual project-structures as well as the artistic output in non-product-based arts[3] are hard to tackle, since their work is often very swift and ephemeral, not even touching the art- discourse and art markets at all.[4] Critical New Media Arts as "artistic research and development" (cf. Borgdorff) between artistic, medial and techno-scientific discourses is research-based and practiceled. They do not produce final products but process artefacts. Creating taxonomies and systemically defining said cultures seems almost impossible.[5] The Next Cultures can be seen as form building elements in regard to the systems theory of Luhmann, borders emerge through self-referred operations which connect with each other (will of cooperation, same codex, same language, same aims, etc.) and are in this sense highly identity establishing. Focussing on the difference that emerges even within such systems, constantly producing new components, structuring such phenomena is relevant only to a limited extent, because the findings might only be common places. It is more interesting to focus on the subsystems, which are persistently altering-despite, or because of their possibility to vanish (or transform) quickly.

Critical (new) media practices that can be described as "art with media" as well as "art that reflects on media" (Reck) are rapidly changing and adapting to the fast evolving media landscape. In times of real-time media and a constantly revving media-usage, scientific descriptions of actual phenomena are only relevant in historic contexts, [6] observing only effects of acceleration, since their immanent speed of circulation is too slow, when compared to the actual speed of discourse and practice in next societies and cultures. While the speed of media usage and consumption rises, concepts such as "art" and "science" (Wissenschaften) change "their essential nature" in terms of "movement and circulation" (Virilio). Looking at the discussions on "When is research artistic?" and the wrongness of that attempt, since "art without research is lacking an essential foundation, as this is the case for science" (see Klein), I am using the term "Artistic Technology" as [dispositif],[7] that can transcend between arts and sciences (Wissenschaften) without touching obvious minefields such as questions whether artists are allowed to do research at all. I am postulating the next artistic science to be not only trans-disciplinary, but another discipline at all that is artistic and scientific at the same time.[8] 
"Artistic Technology Research» observes possible transformations from artistic, technological, playful and "critical engineering"[9] backgrounds to intertwine them using methods (and developing methodologies) that systematically combine research methods from artistic and scientific realms, creating a field of proto-research: "research about/for/ through arts, arts about/for/through research" (Dombois, "0-1-1-2-3-5-8-."). In a two-year timeframe, research is taking place mainly at the University of Applied Arts (Vienna), together with cooperations with the University of Utrecht, various Hacklabs and artist groups among a vast number of researchers and individuals. The project includes a practical approach to problemsolving, so the understanding of "Artistic Technology « is closely related to the greek term of techne[10] and (cf. Raunig)[11] which includes the Critical Arts as well as critique as the "culture of the modern society".[12]

The project is composed of "practices, actions and interactions" (Borgdorff) that will involve diverse audiences and is intended to measure and discuss contemporary (artistic) media practices as well as offering "connections" to social and cultural sciences. Based on "action research" and extending it to include "documentation as method" (and as corrective[13]), the project is designed to connect to open research and open discourses. The entire process will work following an inter- disciplinary approach of knowledge-building and at the same time facilitate popular awareness of applied critical research.

\section{Curating networked discourse}

The core aims of the project "Artistic Technology Research « are to stress the critical discourse in (and about) new media, technology, society and its intersections to art/creativity/ design. The term »Artistic Technology Research « is seen as a vehicle for creating new actions, interactions and interventions that demonstrate critical views, visualizing and re-structuring our Lebenswelt. [14] Critical discourse will be accompanied by tools, formats and publications that will be developed throughout the project. This includes the aims of structuring, visualizing and conveying existing discourses and systems, and opening them up to new audiences.

\section{Documentation as Method}

Documentation is seen as internal (selfobserving) corrective (in terms of action research) as well as subject to research on aesthetic/qualitative parameters of experimental documentation. Starting with the medium "Online Video", the process is designed to include "protocol based media" as well as classical forms of representation and publication.

\section{Narrations for the query public}

In the age of the "query public" we have to radically rethink the concept of the public (cf. Seemann).[15] A change of reception/ perception of audiences can be observed: through multiple, diverse channels of 
consumption and participation, the creation of attention and user-engagement is crucial to any contemporary discourse or research.

The first world is on a path from the "knowledge society" (Bell) passing through the "network society" (Castells, Band 1; Band 2; Band 3) to a possible "next society" as outlined by Dirk Baecker. This opinion-led society[16] values information as main resource, though in an "alliance of news, advertising and entertainment" (Baecker). The "truth" of information is not important anymore, what counts is to get told good stories[17] - as can be seen by the evolution of wikipedia as knowledge resource: mankind can write its history in a collective retrospective (cf. Lovink and Tkacz). Cass Sunstein warns of "Information Cocoons" and "Echo Chamber" effects (Sunstein), "networked knowledge" (as outlined by Weinberger) need precise narratives and new concepts of conveying research results. Addressing the methods of the media and information of the next society, the project aims to develop new narratives and forms of publication, that are fed by documentation as method, networked data-driven science as well as conducting and implementing contemporary art and media practices, that are produced in the wider network, such as by cooperation partners (festivals, researchers, labs, projects, scientists, artists and practitioners). Experiments regarding narratives for the query public will include the dissemination of contents in artistic as well as scientific formats.

\section{Laboratory for process artefacts}

Through empowering cultural artefacts[18] (cf. Schäfer; Lessig, Free Culture) and through enabling technologies it becomes possible to integrate technological ideas into artistic practice without having to think about feasibility in the first place. Artistic practices in this context changed over the last years while still not every cultural artefact necessarily becomes an artistic artefact. The artistic process is describable with the application of artistic knowledge: through transformation-intelligence[19] and contextualising intelligence[20] cultural artefacts are moved in the system of art. In this sense, artistic knowledge (or: artistic intelligence) is the basis for creating artistic capital. [21] Following the success- stories of "Lab Culture" (see also Frost), the projects sets up a space for active work on critical theory and critical engineering. The Lab is an integral part of the project, that will be carried out at the University of Applied Arts.[22]

Cultural accomplishments of individuals or differently organized forms of human beings in context with an ever- changing (transforming) environment bring manifold products and processes to surface: cultural artifacts, "distributed agencies", "framed interactivity" (Rammert), collective ideas. The project's concern is neither popular culture nor technological inventions, but to focus on incidents based on asynergetic potential (cf. Fuller), "creative emergencies"[23] which can be brought up by inter-/trans-/meta- disciplinary and open cultures of production. We need to understand the correlations between culture, technology, codes, art and media to systemically comprehend what next cultures do today to contextualize and state their ideas and concepts. For instance at the progress of an idea, which has different manifestations according to its location in the system of art, in the system of science, or in the system of economy. Critical research is the basis for "experimental systems" that can only be successful if they are offered enough "epistemic things enough room to evolve" (Rheinberger). Recently successful 
"experimental systems" can be described with phenomena such as "critical engineering" and "post-industrial design", just to name a few. The current discourse of "research in the arts" makes art universities prototypical localities, where new forms of research practice and knowledge- production can take place. Said spaces are rare today, in this sense artistic research works as an experimental system for the freedom of sciences and arts - and is to be given space to evolve.

"Artistic Technology Research« aims to work on a discursive and practical level both as a motor for innovation and as a tool with which it is possible to assess the social and artistic/scientific significance of new forms of expression and dissemination. It is important not only to integrate "Artistic Technologies « into an existing theoretical academic discourse, but also to make the results of these studies and the subsequent critical works accessible to the public, extending to the realms of phenomena such as "networked cultures", "bastard cultures" and "coded cultures".

\section{Notes}

[1] Cf. Tarasiewicz, 2011.

[2] Arns further writes: "Media arts dispose themselves of the conceptual exoneration through the novelty of the media and meets the challenge of being artistic. They have (finally)grown up." (translated from Arns).

[3] Such as outlined in Conceptual Art, cf. M.Bochner, S.LeWitt, just to apprehend the statement from an art- historical perspective. While conceptual art was developed and positioned in an arts-context, observing discourses and actual places where "conceptual" and "post-conceptual" arts manifest today are as diverse and fragmented as the current media (and symbolic) landscape.

[4] Lovink $(2003,2008)$ describes this as a "crisis of new media arts", but I cannot share his pessimistic view, since this output can not be positioned into traditional/classical markets without transformation. As he is more a theoretician than a practitioner, his observations are biased.

[5] Obviously it doesn't make sense to observe such heterogenous systems as if they were static and homogeneous, since they are in a constant process of re-structuring and re-formatting, always in resonance to each other.

[6] Since "historic" is a relative term that also changes its meaning with the acceleration (and compression) of written and spoken language and codes, I am referring to the difference of "real-time" to the publication delays of old media. Example: Twitter compared to academic journals. 
[7] Cf. Bussolini, 2010 for the problematics of translating the term appareil/apparato and dispositif/ dispositivo which "produce a false identity in English". This use of the term relates to "Dispositiv" (German) as used by Giorgio Agamben and Gilles Deleuze.

[8] Adressing Rheinberger, this actually means being virtuoso at both scientific and artistic research.

[9] Cf. the "Critical Engineering Manifesto" by J. Oliver, G. Savičić and D. Vasiliev, http://criticalengineering.org

[10] Cf. Heidegger, 1953; and Plato's understanding of techné as knowledge. Techné resembles epistéme in the implication of knowledge of principles, although techné differs in that its intent is making or doing, as opposed to "disinterested understanding." (see Plato in "Gorgias", 399 b.c.)

[11] "[...] the term art is closely related to the greek term techne, therefore in his lecture Foucault states criticism not only as art and virtue, but also as technique. This is not Foucault's quirk, in fact it is a tradition going back to the original uses of the term critique. In Platon's Politikos, the term at first appears as the combination kritiké techne, which means the art, the crafts of distinguishing (translated as "ars iudicandi» in Latin). The label critique as technique and as art can be observed in the course of the centuries and of the different European languages." (translated from Raunig, 2004)

[12] "critique" as the culture of the modern society, starting with book printing. ATR includes parameters of "networked critique".

[13] Cf. Borgdorff, 2011: "research findings give immediate cause for changes and improvements".
[14] In my understanding, Media Arts should illustrate Lebenswelten (lifeworlds), which improve current social situations and critically reflect upon the current hypermedial reality. But Media Art is only able to do so, if it is critically self- reflexive and if it is in stronger regard to the forms of critique of the past. It can only meet economic requirements of the creative industries when it is reduced to a form and object discourse, so it has to be outlined as more than an "economic force".

[15] "The query public is the positive flip side of 'loss of control'. It is that piece of autonomy, the recipient of information gains, which was lost by the sender of that information through the 'loss of control'. (translated from Seemann, 2010).

[16] Cf. Franck, 1998 "the economy of attention", "microcontent" (Nielsen, 1998) as well as the still increasing popularity of Twitter, Facebook and other current social media.

[17] 'If you claim something to be true and enough people agree with you, it becomes true.' Steven Colbert on the word "Wikiality" http://j.mp/ODaVd - "Wikipedia - bringing democracy to knowledge".

\section{[18] Examples of empowering cultural} artefacts and enabling technologies are "Open Hardware" projects such as the Arduino Microcontroller and other "physical computing toolkits", but also the free (open source) operating system Linux can be seen as such. Schäfer sees this as "bastard culture," Lessig "free culture". Extending these uses, critical theory can also be a cultural artefact.

[19] artistic transformation-intelligence describes the basic knowledge of new media artists about the system of "arts" as well as 
the underlying functionalities and operations of cultural and technological artefacts.

[20] artistic contextualising intelligence describes the flexibility of new media artists to position their output (processes, artefacts, discourses, etc.) in other contexts and public(s) e.g. digital public, open discourse, mass media, art audience, selling, etc.

[21] I use the term artistic capital as extension to "cultural capital" (Bourdieu 1982; 1983). In the 21st century artistic knowledge is not only describable through embodied, objectified and institutionalised types of cultural capital. Through cultural evolutions "Free Cultures" (Lessig, 2005), "Bastard Cultures" (Schäfer, 2011) and "Coded Cultures" (5uper.net, 2004) among many other depictions appeared.

[22] "processes of exploration, discovery and innovation matter more than any result these processes ever produce" (The Laboratory at Harvard, 2012).

[23] The Coded Cultures Festival 2009 that was co-curated and co-organized by Matthias Tarasiewicz had the subtitle "exploring creative emergenc(i)es". http:// codedcultures.net

\section{Works cited}

Arns, Inke. "Über Zeitgenossenschaft - Die medialen Künste im Zeitalter ihrer postmedialen Kondition." Kulturpolitische Mitteilungen 2010. Print.

Baecker, Dirk. Zukunftsfähigkeit: 16 Thesen zur nächsten Gesellschaft. 2011. Web. 21 January 2013. http://www. forschungsnetzwerk.at/downloadpub/ baecker2011_16_Thesen.pdf. [http://www. webcitation.org/6Dq6bvpTS].

Bell, Daniel. "The Social Framework of the Information Society." The Computer Age: A 20 Year View. Eds. Michael Dertoozos, and Joel Moses, Cambridge, MA: MIT Press, 1979. 500-549. Print.

Borgdorff, Henk. "The Production of Knowledge in Artistic Research." The Routledge Companion to Research in the Arts. New York: Routledge, Taylor \& Francis, 2011.

Bussolini, Jeffrey. "What Is A Dispositive?" Foucault Studies 2010: 85-107. Print.

Castells, Manuel. Band 1: Der Aufstieg der Netzwerkgesellschaft [1996]. Opladen, Leske + Budrich, 2001. Print.

Castells, Manuel. Band 2: Die Macht der Identität [1997]. Opladen: Leske + Budrich, 2002. Print.

Castells, Manuel. Band 3: Jahrtausendwende [1998]. Opladen: Campus, 2003. Print. 
Dombois, Florian. "0-1-1-2-3-5-8-. Zur Forschung an der Hochschule der Künste Bern." Forschung. Jahrbuch Nr. 4/2009. Bern: Hochschule der Künste Bern, 2009. Print.

Dombois, Florian. "Kunst als Forschung. Ein Versuch, sich selbst eine Anleitung zu entwerfen." Hochschule der Künste Bern 2006. Bern: Hochschule der Künste, 2006. 21-29. Print.

Franck, Georg. Ökonomie der Aufmerksamkeit: Ein Entwurf. München: Carl Hanser, 1998. Print.

Frost, Charlotte. Media Lab Culture in the UK. 2012. Web. 21 January 2013.http:// www.furtherfield.org/features/articles/medialab-culture-uk. [http://www.webcitation. org/6Dq4ivVLt].

Fuller, Buckminster. Operating Manual For Spaceship Earth. New York: Simon \& Schuster, 1969. Print.

Heidegger, Martin. Vorträge und Aufsätze. Stuttgart: Klett-Cotta, 2004. Print.

Kahneman, Daniel. "Thinking That We Know". The New York Times, 2012. Web. 26 September 2012.http://dotearth.blogs. nytimes.com/2012/05/25/daniel-kahnemanon-the-trap-of-thinking-that-we-know/.

Klein, Julian. "What is Artistic Research?" Gegenworte 23. Berlin: Berlin-Brandenburg Academy of Sciences and Humanities, 2010. Print.

Lessig, Lawrence. Code is Law. 2000. Web. 26 September 2012.http://harvardmagazine. com/2000/01/code-is-law.html. [http://www. webcitation.org/6Dq3xVuh9].
Lessig, Lawrence. Free Culture. New York: The Penguin Press, 2005. Print.

Lovink, Geert. Zero Comments. Bielefeld: transcript, 2008. Print.

Lovink, Geert, and Nathaniel Tkacz (eds.). Critical Point of View: A Wikipedia Reader. Amsterdam: Institute of Network Cultures, 2011. Print.

Mersch, Dieter. "Mediale Paradoxa. Zum Verhältnis von Kunst und Medien." sic et non. Zeitschrift für Philosophie und Kultur. 2006. Print.

Nielsen, Jakob. Microcontent: How to Write Headlines, Page Titles, and Subject Lines. 1998. Web. 21 January 2012. http:// www.nngroup.com/articles/microcontenthow-to-write-headlines-page-titles-andsubject-lines/. [http://www.webcitation. org/6Dq3Jjwel].

Pang, Alex Soojung-Kim, and David Pescovitz. "Cyberspace is Dead." Wired Magazine. February 2006. Print.

Rakuschan, F. E., and Matthias Tarasiewicz. Coded Cultures - Decoding Digital Culture. 2004. Web. 26 September 2012. http:// codedcultures.5uper.net. [http://www. webcitation.org/6Dq2sACaD].

Rammert, Werner. Where the Action is: Distributed Agency Between Humans, Machines, and Programs. Berlin: Technical University Technology Studies Working Papers, 2008. Print.

Raunig, Gerald, and Ulf Wuggenig. "Kritik der Kreativität. Vorbemerkungen zur erfolgreichen Wiederaufnahme des Stücks Kreativität." Kritik der Kreativität. Eds. 
Gerald Raunig and Ulf Wuggenig. Wien/ Berlin: Turia+Kant, 2007. Print.

Raunig, Gerald. "Aussetzung und Neuzusammensetzung in textuellen und sozialen Maschinen." Kunst der Kritik. Republicart 10. Eds. Birgit Mennel, Stefan Nowotny and Gerald Raunig. Wien/Berlin: Turia+Kant, 2004. Print.

Reck, Hans U. Mythos Medienkunst. Köln: Kunstwissenschaftliche Bibliothek, 2002. Print.

Rheinberger, Hans-Jörg.

Experimentalsysteme und epistemische Dinge. Eine Geschichte der Proteinsynthese im Reagenzglas. Göttingen: Wallstein, 2001. Print.

Schäfer, Mirko Tobias. Bastard Culture!. Amsterdam: Amsterdam University Press, 2011. Print.

Seemann, Michael. "Vom Kontrollverlust zur Filtersouveränität." \#public_life. Digitale Intimität, die Privatsphäre und das Netz. in: Ed. Heinrich-Böll-Stiftung. Berlin, 2011. Print/Web. 21 January 2012.http://www. boell.de/downloads/2011-04-public_life.pdf. [http://www.webcitation.org/6DpyEijBw].

Sunstein, Cass R. Republic.com 2.0. New Jersey: Princeton University Press, 2007. Print.

Tarasiewicz, Matthias. "Coded Cultures Between New Media Arts and Production Cultures." Coded Cultures - New Creative Practices Out Of Diversity. Ed. Georg Russegger, Matthias Tarasiewicz and Michal Wlodkowski. Wien/New York: Springer Edition dieangewandte, 2011. Print.
The Laboratory at Harvard. Web. 26 September 2012. http://thelaboratory.harvard.edu.[http://www.webcitation. org/6DpxB1Ffn].

Virilio, Paul. Geschwindigkeit und Politik: ein Essay zur Dromologie. Berlin: Merve, 1977. Print.

Weinberger, David. Too Big to Know: Rethinking Knowledge Now That the Facts Aren't the Facts, Experts Are Everywhere, and the Smartest Person in the Room Is the Room. New York: Basic Books, 2012. Print. 